\title{
Quo Vadis, Business? The migration of companies between cities using the example of the Mazowieckie voivodship in Poland
}

\begin{abstract}
Relations between metropolitan core cities and regional and sub-regional centres are part of a broader discussion on the importance of metropolitan areas for the development of regions. These relations are dealt with in this paper in the context of the growth pole theory. The paper focuses on the migration process in relation to enterprises. By moving their businesses, companies contribute to backwash and spread effects. Since company migrations between municipalities occur in both directions, the question remains open as to which migration direction dominates - whether from sub-regional centres to core cities or vice versa. This paper attempts to verify the hypothesis that regional and sub-regional centres in the Mazowieckie voivodship suffer the largest loss of enterprises due to migration to the core city of Warsaw. The results obtained were varied and the hypothesis was confirmed, especially in the case of three cities: Siedlce, Radom and Płock; and partly in the case of Ciechanów.
\end{abstract}

\section{Keywords}

Warsaw $\cdot$ regional city $\cdot$ sub-regional city $\cdot$ polarisation $\cdot$ migration of companies $\cdot$ net migration

(C) University of Warsaw - Faculty of Geography and Regional Studies

Introduction

The subject discussed in this paper fits into the broader issue of relations between metropolitan areas and their regions, which has been a subject of interest to both scientists and practitioners who have been implementing various development policies for many years, as well the scenarios describing the future (Korcelli-Olejniczak \& Korcelli 2015). The description of these relations is traditionally derived from the concept of growth poles (Perroux 1978; Grzeszczak 1978). In the context of this theory and its spatial implementation (Myrdal 1957), questions have been asked about the effects of growth poles on the environment. The issue of analysing backwash effects and spread effects has been addressed (Grzeszczak 1999). The important question is to what extent core cities drain resources from regions (other cities) and to what extent they affect positive change.

This paper analyses the relocation of companies to and from Warsaw (which is the largest city in Poland and the core city in the Warsaw Metropolitan Area), and the regional (Radom and Płock) and sub-regional centres (Siedlce, Ciechanów \& Ostrołęka), as described in The Development Strategy of the Mazowieckie voivodship (Strategia Rozwoju Województwa Mazowieckiego 2013) (Figure 1). The problem of distinguishing and classifying growth poles in the Mazowieckie voivodship and wider Poland has been discussed many times but there is a diversity of methodological approaches that results in differences in the delineation of subregional growth centres (Szlachta 2011; Wojnicka-Sycz 2013). The cities distinguished in the Mazowieckie voivodship form a specific group of former voivodship capitals in the present Mazowieckie voivodship. ${ }^{1}$

${ }^{1}$ In 1975-1998, there were 49 voivodships in Poland but in 1999 the administrative division had been reduced to 16 voivodships. The Mazowieckie voivodship is located in

\author{
Magdalena Cybulska $\mathbb{C}$, \\ Wojciech Dziemianowicz \\ Chair of Urban Geography and Spatial Planning, Faculty \\ of Geography and Regional Studies, University of \\ Warsaw, Warsaw, Poland \\ e-mail: magdalena_cybulska@uw.edu.pl \\ e-mail: w.dziemianowicz@uw.edu.pl \\ Received: 12 June 2019 \\ Accepted: 8 September 2020
}

The aim of the paper is to verify the hypothesis that: subregional and regional cities of the Mazowieckie voivodship are characterised by the loss of companies because of mainly Warsaw-bound migration. This hypothesis is tested for all companies as well as for all companies excluding sole proprietorships. ${ }^{2}$

Migrations of companies as an effect of mutual influence of cities

The discussion on growth poles also touches on the agglomeration issue (McCann \& van Oort 2009), and tries to answer the question regarding the reasons for the concentration of people or companies in a particular place. In turn, the agglomeration can be considered in the context of business location theory (Weber 1909; Hoover 1962; McCann \& Sheppard 2003) as one of the location factors and, for example, within regional development theory, in which it is perceived as the driving force of development (Capello 2009; Maier \& Trippl 2009; Perry 2010; Camagni, Capello \& Caragliu 2015).

The process of the accumulation of companies in a given place may also be considered in the discussion on endogenous development (Minerva \& Ottaviano 2009) as well as in the external context, for example in interregional competition (Jirásková 2013; Camagni 2017). In this case a lot of space in the discussion is devoted to foreign direct investments (FDI), which are a symptom of the expansion of transnational corporations - there is an

central Poland and its capital city is Warsaw. The lowest units of administrative division are municipalities that constitute counties.

${ }^{2}$ Sole proprietorship refers to a natural person who is an entrepreneur entered on the REGON register (the register of all entities of the national economy maintained by the president of Statistics Poland). This is one of the simplest organisational forms of enterprise 
increase in the number of countries in which a given company operates (Capello, Fratesi \& Resmini 2011) - but it also happens that economic operators transfer their activities from one country to another, and cease their activity in one country in favour of another (Dunning \& Lundan 2008).

A separate area of analysis considers the location factors of both domestic and foreign companies at various spatial levels (from location determinants in a given country to specific investment areas in a specific municipality) (e.g. Zdanowska 2017; Dziemianowicz, Łukomska \& Ambroziak 2018).

In this area, an important part of the research has been the soft location factors (Grabow, Henckel \& Hollbach-Grömig 1995; Clodnițchi 2017), in which the needs of the entrepreneur as a resident of a given city or a given municipality are considered. It can be assumed that these soft locational factors (e.g. quality of schools, leisure options) allow us to combine the issue of the relocation of companies with the issues of population migration. Entrepreneurs run their businesses but, at the same time, they and their families consider the quality of life in the area in which their businesses are located (Leigh \& Blakely 2017). In search of better living conditions, they can carry their small businesses with them. In studies on the factors that influence the location of enterprises in the Mazowieckie voivodship, the proximity of the residence of the founder or owner of a company in the case of microenterprises is indicated as significant, regardless of the company's industry (Dziemianowicz, Mackiewicz \& Zaleski 2012).

Warsaw attracts businesses due to both hard and soft location factors (see Grabow, Henckel \& Hollbach-Grömig 1995). On the one hand, factors such as local market potential, access to knowledge (universities, R\&D), human capital (education, qualifications of residents), possibilities for business cooperation, the cultural offer, the quality of life or the prestige of the location are the domain of the largest urban centres and may be conducive to choosing these centres as a business location. Such location factors may give a competitive advantage to Warsaw, compared with the smaller cities of the Mazowieckie voivodship, in attracting certain kinds of businesses as well as providing a place to live (e.g. Dziemianowicz, Jałowiecki \& Krajewska 2004; Rossi \& Dej 2019).

On the other hand, high taxes, strong competition, property prices or high wages in the local market may discourage such a decision (e.g. Cieślik 2005). The importance of the capital and its proximity, in the study of entrepreneurs in the Mazowieckie voivodeship, has been emphasised by microenterprises but also by small and medium-sized enterprises operating in the services sector (Dziemianowicz, Mackiewicz \& Zaleski 2012).

In the migration literature, numerous studies have been carried out on the relocation of companies based on their characteristics (e.g. Brouwer, Mariotti \& Ommeren 2004) or migration within metropolitan areas (Dej, Jarczewski \& Chlebicki 2018). The problem of relocation is also considered in relation to the migration of business owners. Studies on the relocation of companies and the migration of their owners have shown that the location of the enterprise can change when the owner chooses better living conditions (Niedomysl et al. 2019). Moreover, studies have shown that the scale of migration decreases as the size of the company increases (e.g. Brouwer, Mariotti \& Ommeren 2004). Therefore, it is possible to observe differences between relocations (regarding the direction and the reasons for changing the place of business) of sole proprietorships and other firms. The third aspect is the relocation of companies from city centres to peripheral areas, which affects core cities and their metropolitan areas most often (Dej 2015; Dej, Jarczewski \& Chlebicki 2018).

In the face of various behaviours of entrepreneurs migrating in different directions, the answer to the following question should be interesting: can it be said that the largest city of the voivodship drains the economic potential from other centres? The answer to this question is not at all unambiguous. Additionally, assuming that the migration of small companies may take place along with population migration as part of the suburbanisation process, it is not clear which has a greater impact on the city.

\section{Data and research method}

The migration of companies, as the subject of the study, corresponds to the change in the registered place of business (at the municipal level); therefore, this refers to the transfer of the seat of the whole entity only, and excludes partial migration. The business addresses of companies were compared between 2014 and 2016 based on data from the REGON register. The terms 'migration' and 'relocation' are used interchangeably in the paper. ${ }^{3}$ We used the indicator method in the analysis. The main indicators are:

- net migration, indicating the strength of migration flow and percentage of migration to characterise migration directions; - location quotient (LQ) and Gini index to analyse the concentration of migration in Warsaw.

In order to show the relations between cities and their nearest surroundings, the net migration of county areas surrounding county centres was separated into the net figure for the dominant municipality (the highest migration value) and the remaining part of the county. Due to the fact that companies of various sizes migrate, and a significant number of small companies relocate as a result of migratory movements, we decided to undertake a two-dimensional analysis of migration: (A) all companies; (B) all companies excluding sole proprietorships.

The scale of company migrations and the relations between Warsaw and other municipalities

In 2014 to 2016 almost half of the municipalities in Poland (46\%) recorded a negative net migration of enterprises (Figure 2). In the country, including in the Mazowieckie voivodship, the negative net migration was dominant for urban municipalities. In the Mazowieckie voivodship, a positive value occurred primarily in Warsaw and in some urban areas belonging to its metropolitan area. The general picture did not change significantly after the smallest companies were excluded from the analysis. It is true that the scale of migration was lower and fewer communes $(34 \%)$ recorded a negative net migration; however, the spatial concentration of the phenomenon was similar.

Warsaw's positive net migration does not mean, however, that the majority of entities in Poland lose companies in favour of the capital city. It is true that there are many more municipalities compared with which Warsaw had a positive net migration but, in many cases, the level of flows was low. All sub-regional and regional cities of the Mazowieckie voivodship recorded a negative net migration in their relations with Warsaw.

The relations between Warsaw and other municipalities in Poland have two specific features. First, the largest flows have taken place between the capital city and other large cities and between Warsaw and its immediate surroundings. Second, the capital city has often lost companies to the benefit of neighbouring municipalities, which can be linked to the processes of population migration (Figure 3). After the exclusion of sole proprietorships, the scale of migration decreased significantly. The general picture of relations between Warsaw and other municipalities also changed.

\footnotetext{
${ }^{3}$ The concept of relocation covers the migration of entire enterprises as well as partial migration, i.e. delocation (Małuszyńska 2013).
} 


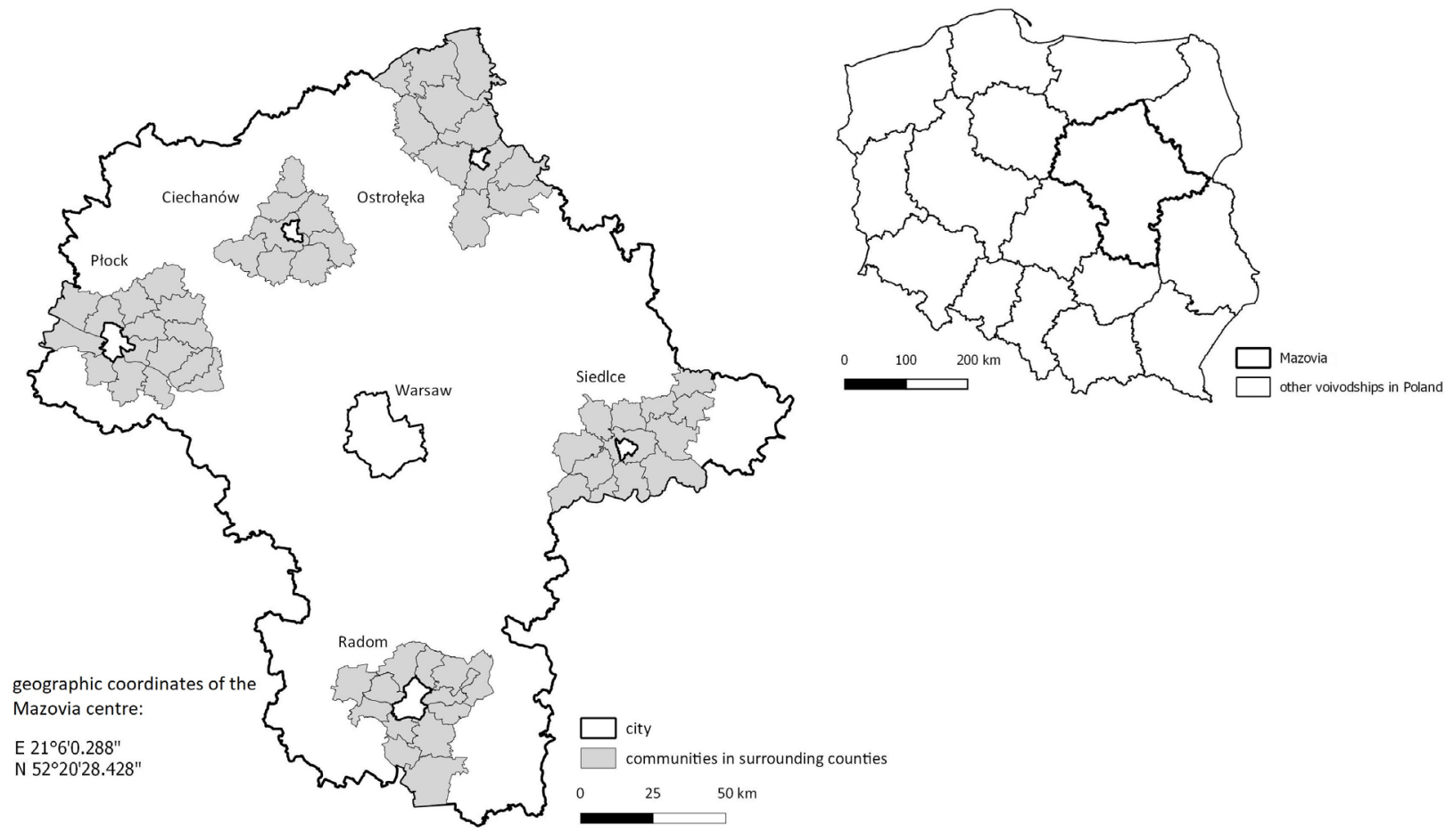

Figure 1. Location of Warsaw and sub-regional and regional cities with their counties (powiaty) in the Mazowieckie voivodship (which the map on the right shows in relation to Poland)

Source: own study (illustrative figure not including the full territorial division of the voivodship).

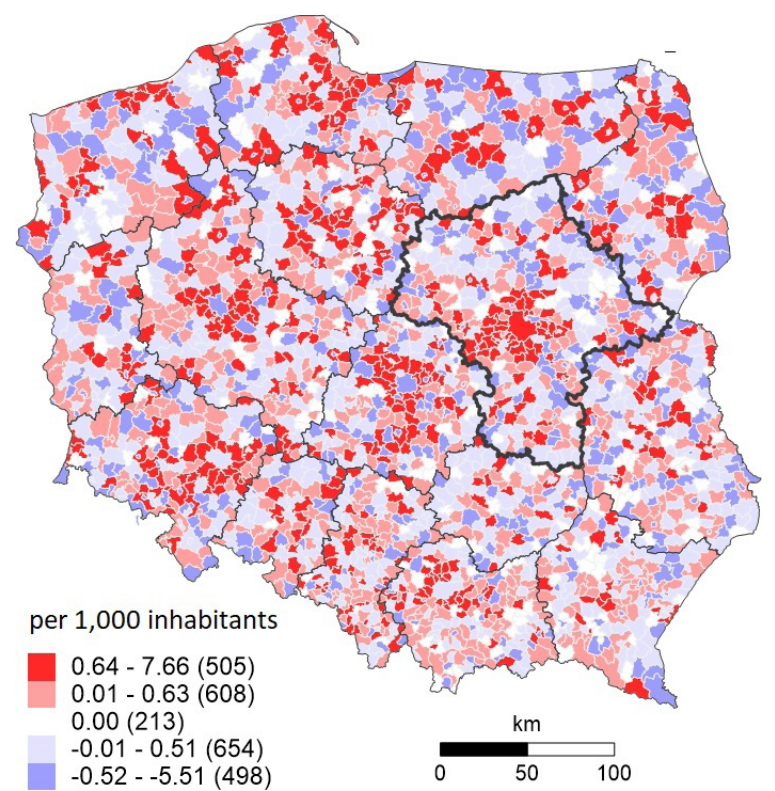

A

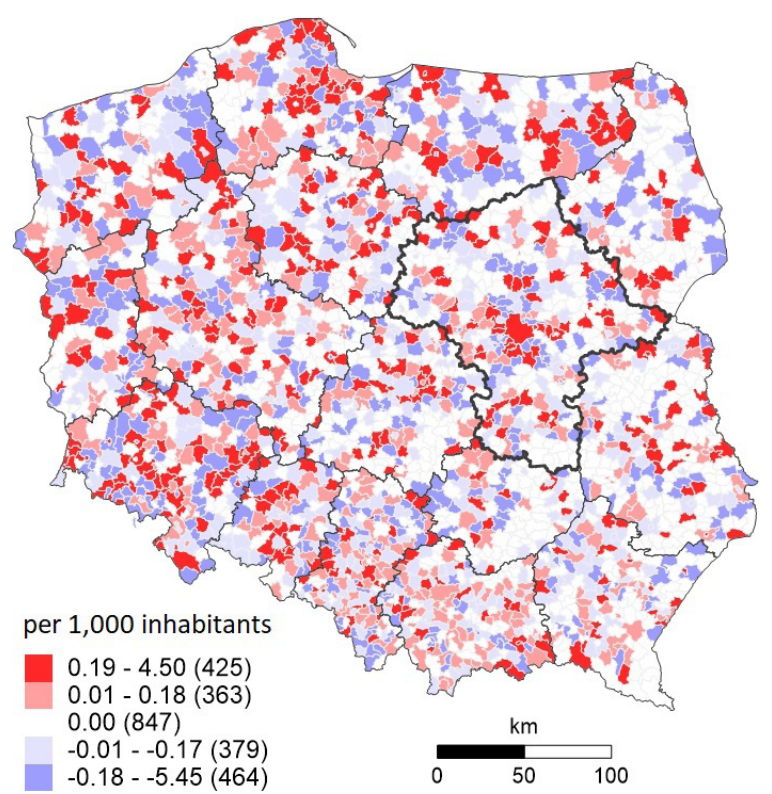

B

Figure 2. Net migration of companies in municipalities in Poland in 2014-2016

$A$ - all companies

$B$ - all companies excluding sole proprietorships

(The values in brackets are the number of municipalities.)

Source: own study based on data from the Statistical Office in Warsaw. 

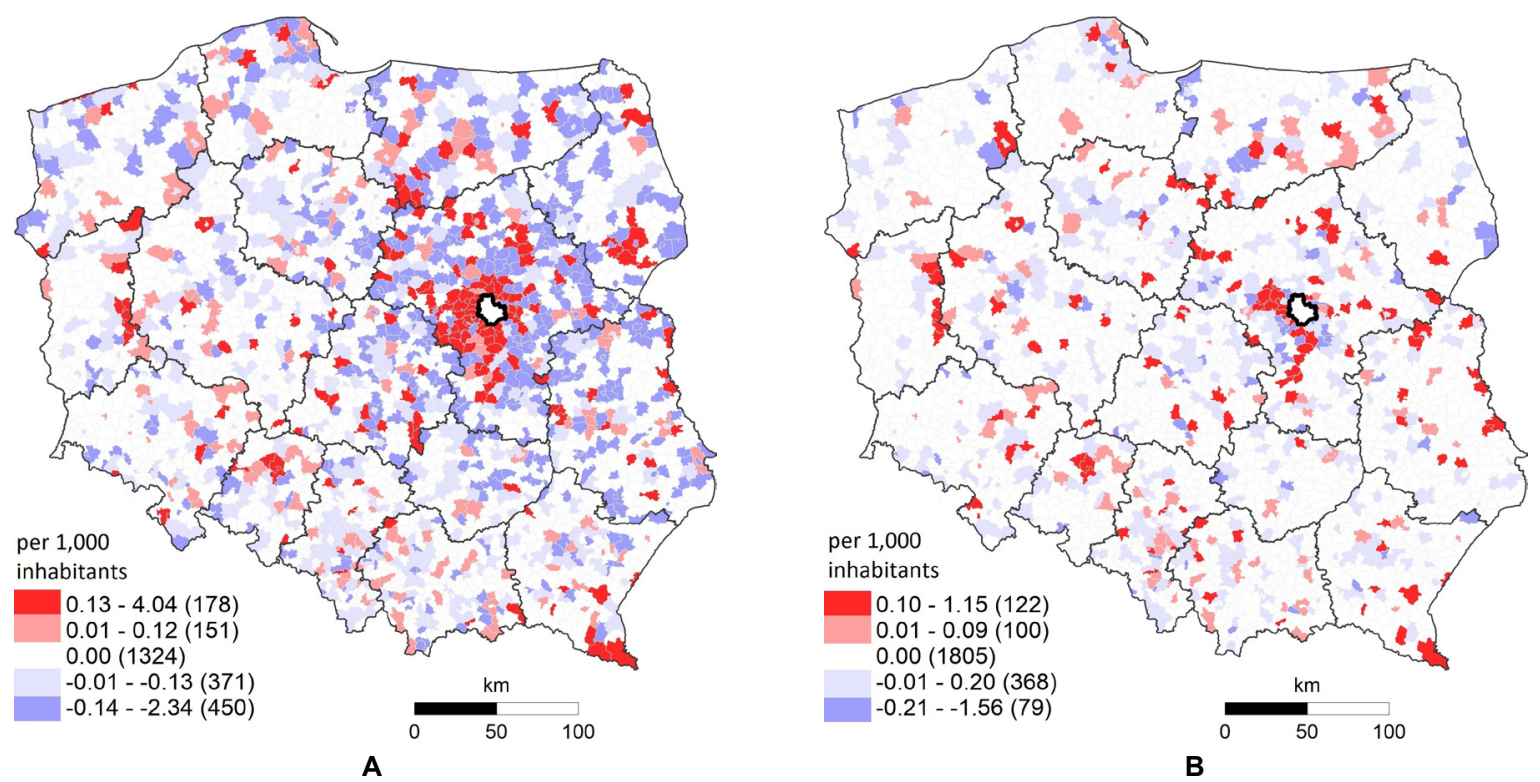

Figure 3. Net migration of companies in relation to Warsaw in 2014-2016

A - all companies

$B$ - all companies excluding sole proprietorships

(The values in brackets are the number of municipalities.)

Source: own study based on data from the Statistical Office in Warsaw.

Migration of companies in regional and sub-regional cities of the Mazowieckie voivodship

All the cities studied are characterised by a predominance of small enterprises, including sole proprietorships, which are affected by the highest mobility (Migrations of enterprises in sub-regional cities... 2018). A particularly high percentage of self-employment occurs in Ostrołęka and in Radom (approx. 76\% of all companies in 2016 were sole proprietorships). The lowest number of entities employing up to nine people was in Płock. No companies employing more than 1,000 people were reported in any city, but the percentage of medium and large companies was high in Płock. ${ }^{4}$ The net migration of populations in the cities studied and the surrounding municipalities indicates the suburbanisation process taking place, primarily in municipalities that border the city directly. ${ }^{5}$

In the first step, the Gini index was calculated in order to show the strength of Warsaw's influence (Table 1). The values show a particularly strong outflow of companies to Warsaw in the case of Ciechanów (the highest decrease in the index when Warsaw has been excluded) and the lowest in the case of Ostrołęka. The cases of Płock, Radom and Siedlce also show a strong influence from municipalities other than Warsaw. The calculated inflow values indicate a more even distribution of migration and a smaller impact from Warsaw.

Taking into consideration the detailed spatial distribution of the migrations of all companies, we can see that (apart from Warsaw) the accumulation of flows occurred in municipalities in the immediate vicinity of cities. Warsaw and its neighbourhood account for $65-75 \%$ of all migrations while other migration directions are much fewer in number (see Figure 6A-15A,

${ }^{4}$ Data from BDL GUS (https://bdl.stat.gov.pl/BDL/start).

5 In the case of Ostrołeka, the net migration of the population was particularly low (-7.6 per 1,000 inhabitants in 2016). At the same time, four municipalities from Ostrołęck county had positive net migration (data from BDL GUS). The analysis shows a strong correlation between the migration of people and the relocation of companies (Migrations of enterprises in sub-regional... 2018).
Table 1. Gini index of the migration of all companies in regional and sub-regional cities

\begin{tabular}{|c|c|c|c|c|}
\hline \multirow{2}{*}{ City } & \multicolumn{4}{|c|}{ Gini index (total) } \\
\cline { 2 - 5 } & \multicolumn{2}{|c|}{ including Warsaw } & \multicolumn{2}{c|}{ excluding Warsaw } \\
\cline { 2 - 5 } & inflow & outflow & inflow & outflow \\
\hline Ciechanów & 0.39 & 0.50 & 0.33 & 0.36 \\
\hline Ostrołęka & 0.48 & 0.61 & 0.42 & 0.56 \\
\hline Płock & 0.51 & 0.64 & 0.45 & 0.55 \\
\hline Radom & 0.52 & 0.62 & 0.42 & 0.51 \\
\hline Siedlce & 0.53 & 0.64 & 0.47 & 0.55 \\
\hline
\end{tabular}

Source: own study based on data from the Statistical Office in Warsaw.

(Values closer to 1 indicate uneven distribution.)

compare Migrations of enterprises in sub-regional cities... 2018) The migration figures are often the highest in Warsaw. The only exception is Ostrołęka, where another municipality has the highest inflow from the city.

These facts are interesting in the context of further analysis in terms of the impact (the net migration) on each municipality. Again, the area outside Warsaw and the suburban areas of cities were of marginal importance in terms of net migration (see Annex).

When comparing these two dominant areas of migration, there are several aspects to consider. The migration processes involving the immediate environment took place at a similar level in both directions (outflow and inflow) while in the case of Warsaw a significant increase in the migration rate occurred in 
Ciechanów

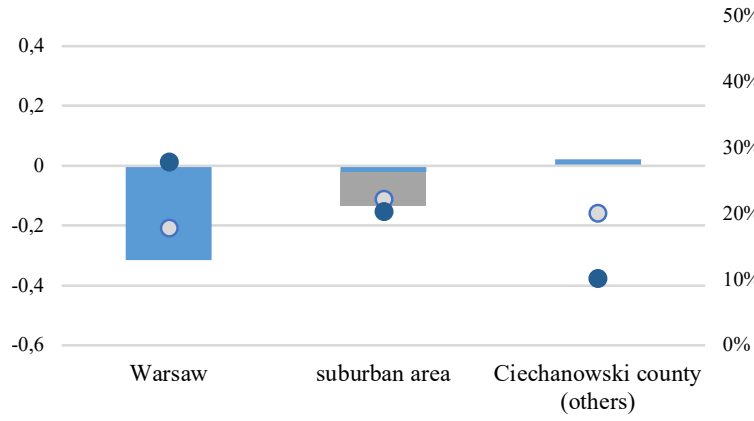

Płock

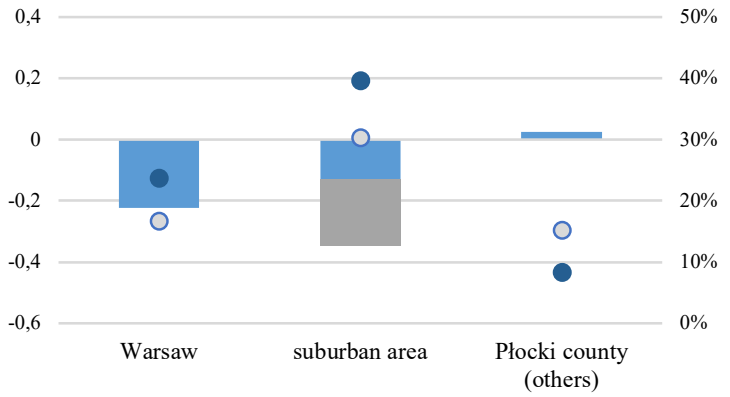

Ostrołęka

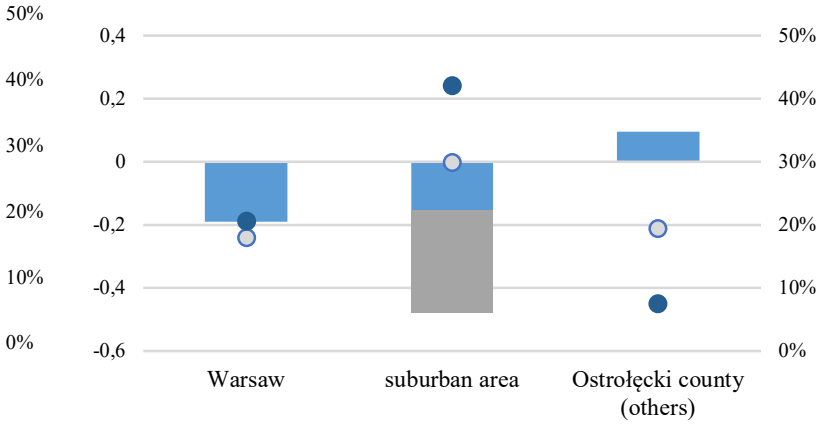

Radom

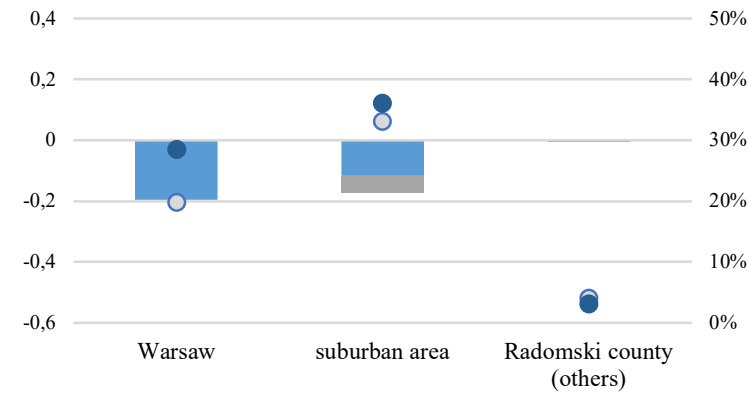

Siedlce

\section{.} . $\%$ 


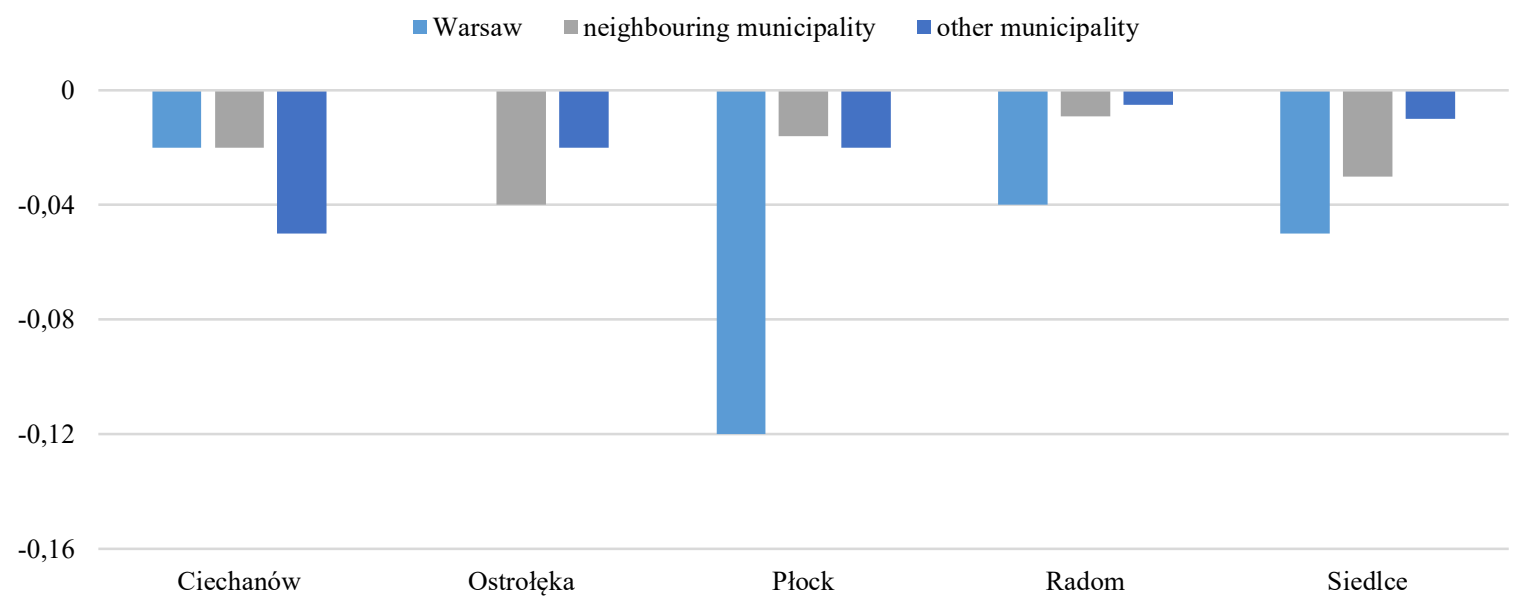

Figure 5. Net migration of companies excluding sole proprietorships per 1,000 inhabitants in relation to cities with selected municipalities In addition to Warsaw, the relation with the neighbouring municipality and another municipality in Poland that has the largest negative impact on the city has been shown.

Source: own study based on data from the Statistical Office in Warsaw.

Table 2. Gini index of the migration of all companies excluding sole proprietorships in regional and sub-regional cities

\begin{tabular}{|c|c|c|c|c|}
\hline \multirow{2}{*}{ City } & \multicolumn{4}{|c|}{ Gini index } \\
\cline { 2 - 5 } & \multicolumn{2}{|c|}{ including Warsaw } & \multicolumn{2}{c|}{ excluding Warsaw } \\
\cline { 2 - 5 } & inflow & outflow & inflow & outflow \\
\hline Ciechanów & 0.22 & 0.26 & 0.17 & 0.1 \\
\hline Ostrołęka & 0.25 & 0.25 & 0 & 0.17 \\
\hline Płock & 0.41 & 0.53 & 0.25 & 0.21 \\
\hline Radom & 0.41 & 0.48 & 0.17 & 0.16 \\
\hline Siedlce & 0.26 & 0.39 & 0.17 & 0.22 \\
\hline
\end{tabular}

Source: own study based on data from the Statistical Office in Warsaw.

(Values closer to 1 indicate uneven distribution.)

the outflow of companies from other areas to Warsaw (Figure 4). The negative impact of the neighbouring areas increased mainly in the adjacent municipalities and decreased as the distance from the cities increased. In each of the cities there was a municipality in which there was a clear accumulation of the outflow of companies.

A detailed analysis shows several characteristic features of the individual centres:

- in the case of Ostrołęka only, a single neighbouring municipality drained the city of companies, having a greater effect than that of Warsaw (absolute net migration respectively: -25 and -17 );

- a very specific situation was found in Płock, where the entire suburban area had a much greater effect on Płock than the capital city, and one of the neighbouring municipalities drained the city to an extent comparable to Warsaw (-26 and $-27)$;

- the high importance of Warsaw and the low importance of the suburban area can be noted in the case of Ciechanów - the negative impact of the capital city was strengthened by its metropolitan area ( -5 for the dominating municipality of the suburban areas and -24 jointly for the metropolitan area of Warsaw);

- $\quad$ in the case of Siedlce and Radom, the highest losses of companies took place in favour of Warsaw (-24 and -42). The impact on the whole Siedlecki and Radomski county was comparable to the impact on the capital city (-23 and -38$)$.

When sole proprietorships and Warsaw are excluded, migration patterns are more evenly distributed (the values of the Gini index were closer to 0 ). In the case of outflow, the index was particularly high for Płock. The highest decrease in the outflow ratio can be seen for Radom, Siedlce and Płock (Table 2).

All the analysed growth centres in the Mazowieckie voivodship continued to have a negative net migration when sole proprietorships were excluded. However, the capital city was not always the most negatively affected of the cities analysed. The range of impacts on municipalities shows a separate specificity for particular cities (Figure 5). In two cities (Ciechanów and Ostrołęka), the influence of the capital city is so low that individual small municipalities exerted a stronger influence. At the same time, it is worth emphasising the marginal scale of relocation in those cases (compare Table 2, Figure 6B-15B). Therefore, in principle, further analysis and conclusions are not possible. What is certain in this case is the great extent of the migration of sole proprietorships from Ciechanów to the capital city. In Ostrołęka, the net migration with the county was negative, in contrast to the neutral relations between it and the capital city. Also, when the smallest companies are omitted, we can talk about the stronger influence of the surroundings on Ostrołęka.

Plock recorded the highest negative net migration in its relations with the capital city (both in absolute value and in terms of inhabitants) ${ }^{6}$ and it is the only city that recorded a higher inflow than outflow of companies compared with the neighbouring municipalities.

A very similar structure of relocation of companies in the analysed period took place in Radom. The negative net migration

${ }^{6}$ In comparison to the scope of the phenomenon in Poland, the scale of the impact was small (over 100 units in the country with a lower net migration). 

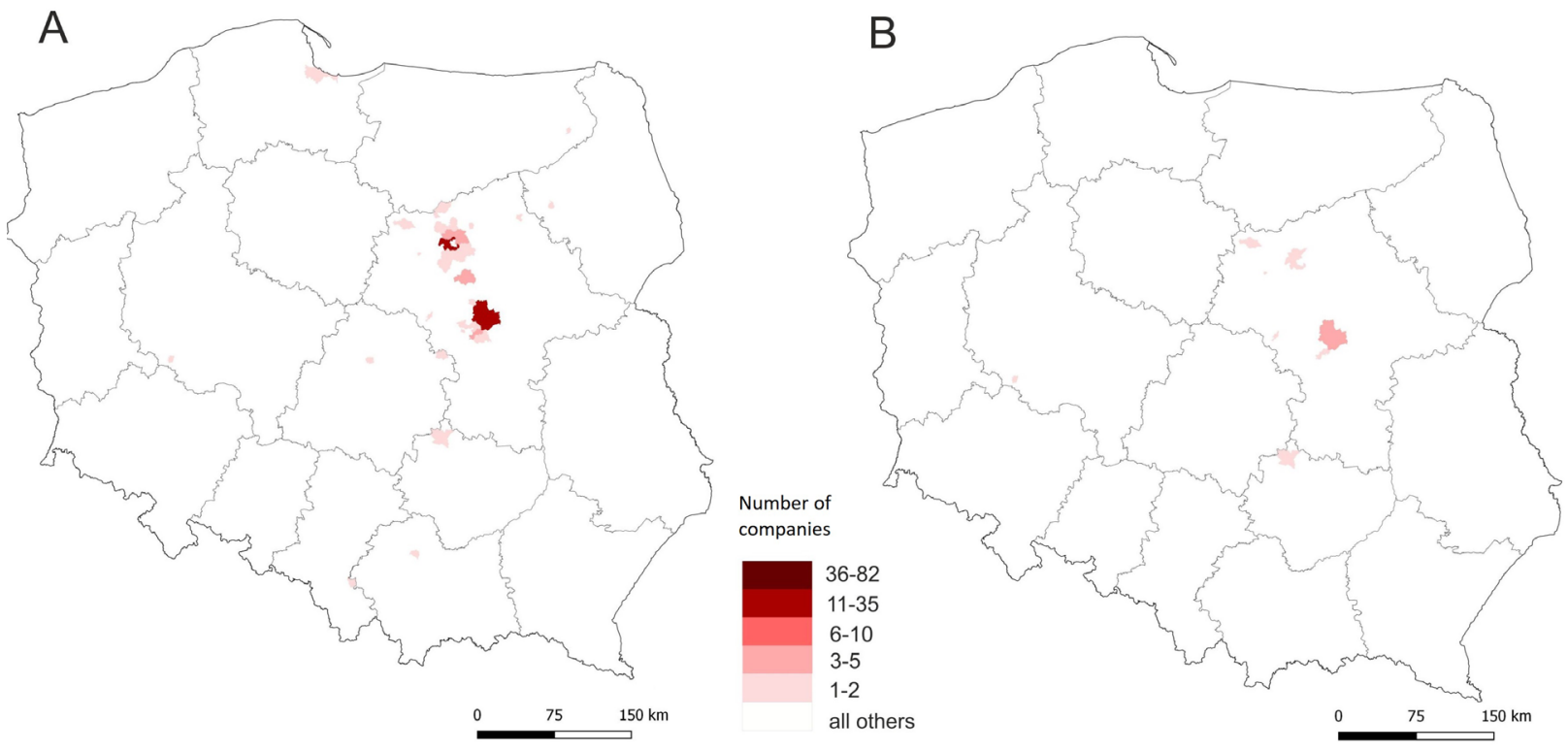

Figure 6. Number of companies that relocated from Ciechanów to other municipalities (outflow)

$B$ - all companies excluding sole proprietorships

Source: own study based on data from the Statistical Office in Warsaw.
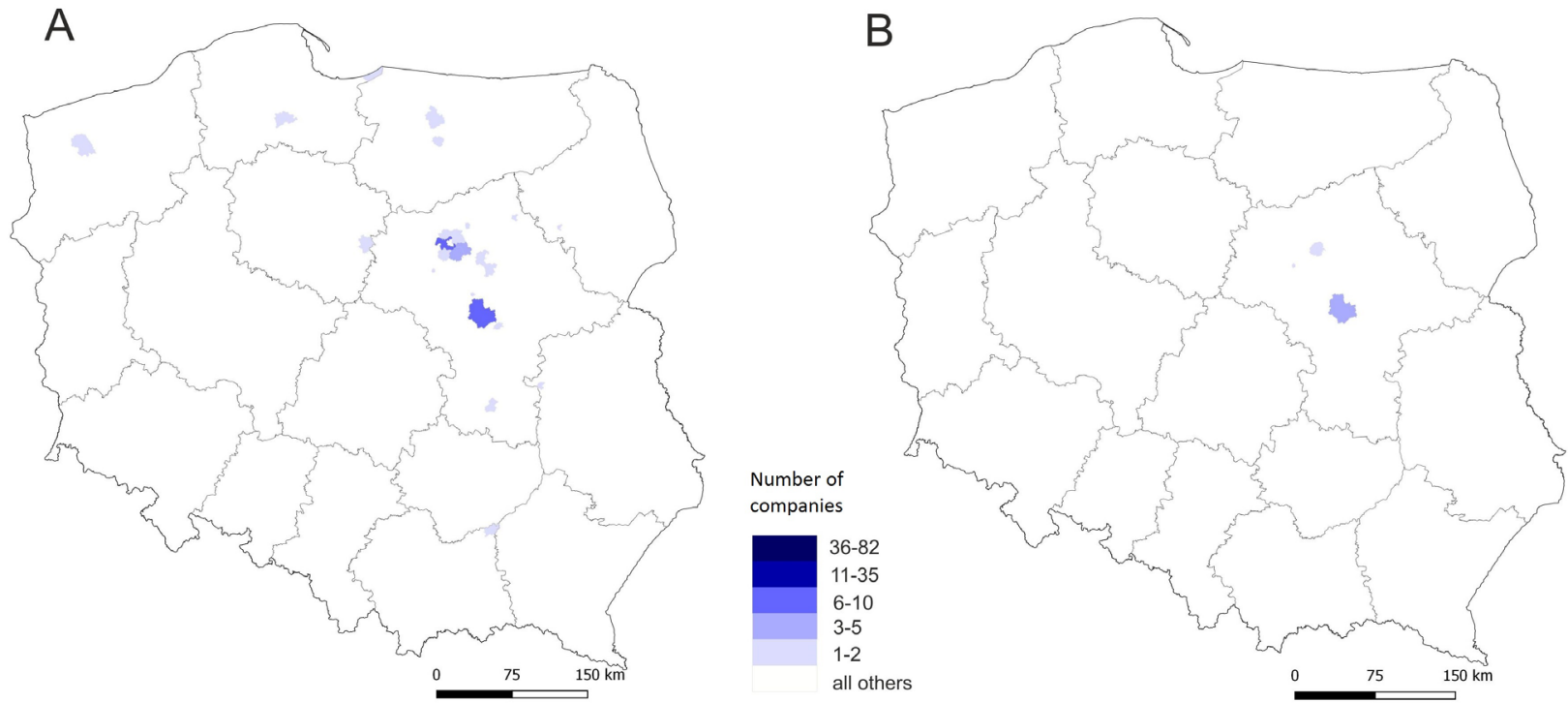

Figure 7. Number of companies that relocated to Ciechanów from other municipalities (inflow)

$A$ - all companies

$B$ - all companies excluding sole proprietorships

Source: own study based on data from the Statistical Office in Warsaw.

with the capital city was also high and although the balance with the immediate surroundings was still unfavourable, none of the municipalities had a stronger negative impact on Radom than Warsaw. In the case of Siedlce the net migration was negative with the capital city. Similar to the cases of Radom and Płock, Warsaw still had the strongest influence, but the effect was lower in comparison to those cities.
The above data compared the scale of migration and the impact of Warsaw among all regional and sub-regional cities but did not fully show the national context. Comparison of the location quotient (LQ) of the inflow and outflow of companies in relation to Warsaw (Table 3 ) shows that both the inflow and outflow processes are intensive (LQ> 1.25). Flows are not the highest in the country but the results show the strong influence of 

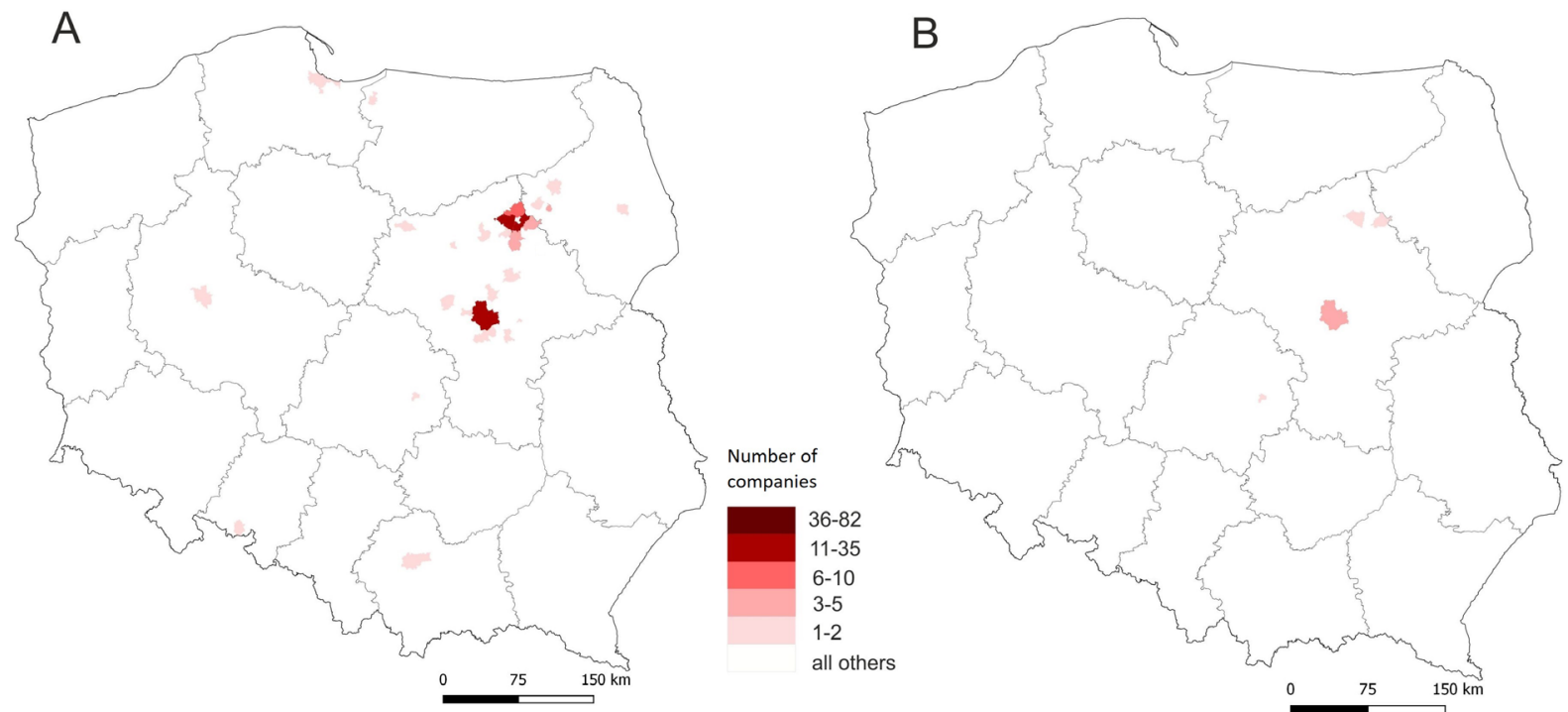

Figure 8. Number of companies that relocated from Ostrołęka to other municipalities (outflow)

$A$ - all companies

$B$ - all companies excluding sole proprietorships

Source: own study based on data from the Statistical Office in Warsaw.
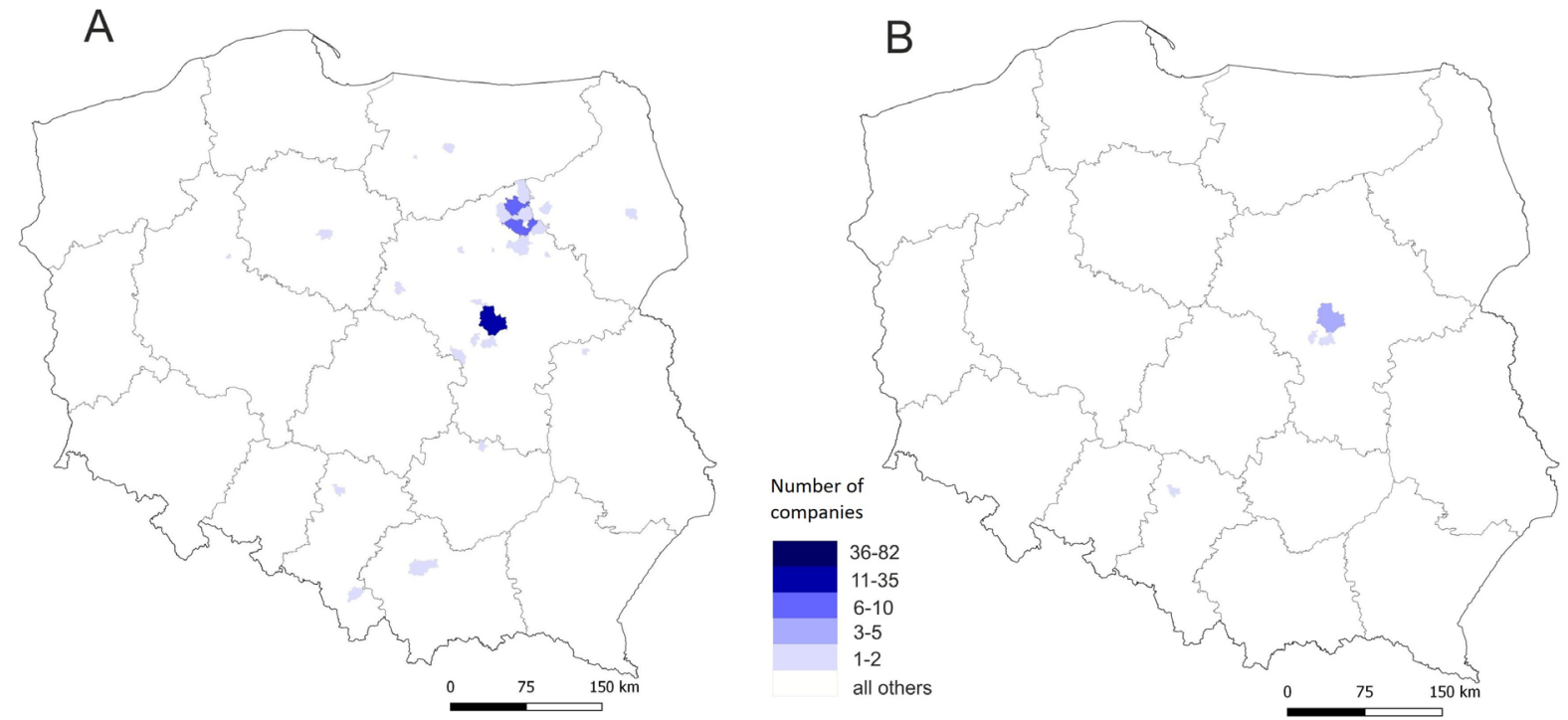

Figure 9. Number of companies that relocated to Ostrołęka from other municipalities (inflow)

$A$ - all companies

$B$ - all companies excluding sole proprietorships

Source: own study based on data from the Statistical Office in Warsaw.

Warsaw. In addition, they confirm the specific status of Ostrołęka. At the same time, the level of net migration with Warsaw in cities was incomparable with the lowest values in Poland (-2.34 and -1.55 excluding sole proprietorships).

\section{Discussion}

The issue of the migration of companies related to population migration is not easy to analyse in the context of the possibility that local authorities try to keep entrepreneurs within their city boundaries. The study showed that the smallest companies migrate to the greatest extent, so motivations to relocate can be for both personal and, typically, business reasons. How can a municipality retain its firms? The answer is not unambiguous, and the important issue is not only to implement typical pro-investment policies (such as shaping tax policy, creating incentives for entrepreneurs, elements of 'post-investment service'), but also incentives based on cultural, housing and/or social offerings (see Jarczewski 2012; Dziemianowicz, Mackiewicz \& Zaleski 2012; Niedomysl et al. 2019). 
A

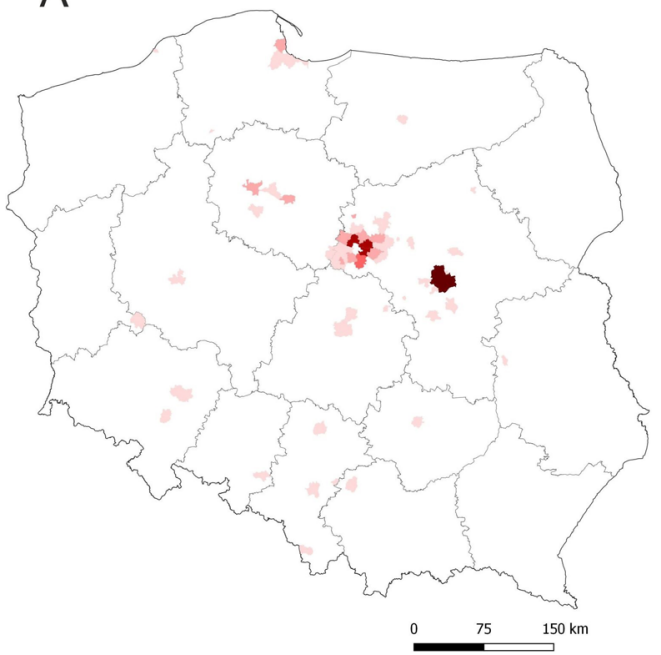

B

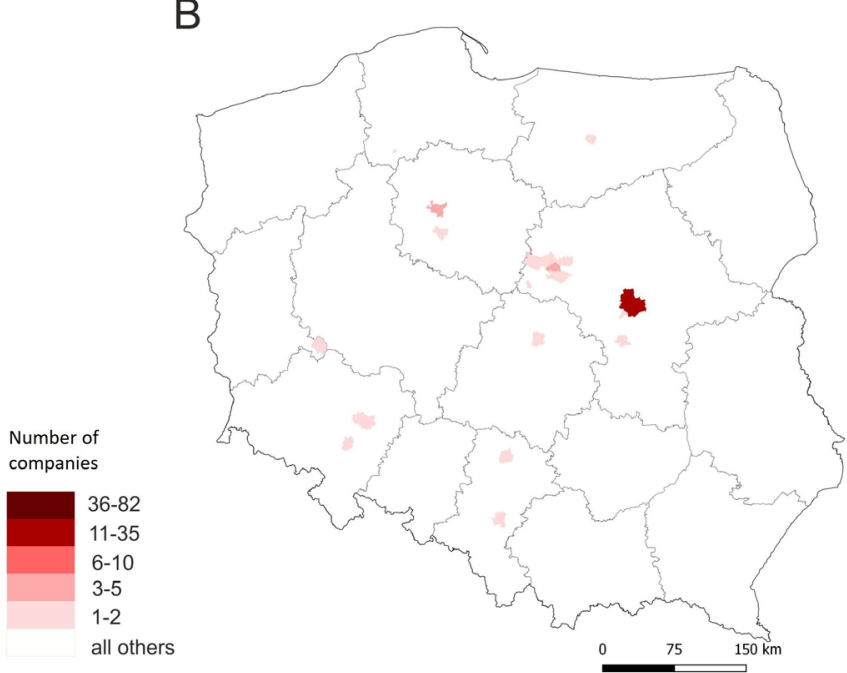

Figure 10. Number of companies that relocated from Płock to other municipalities (outflow)

$A$ - all companies

$B$ - all companies excluding sole proprietorships

Source: own study based on data from the Statistical Office in Warsaw.

A

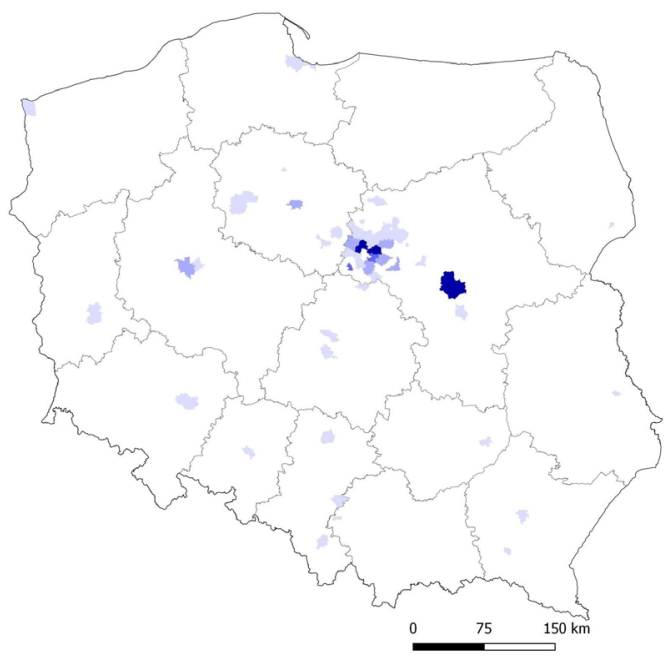

B

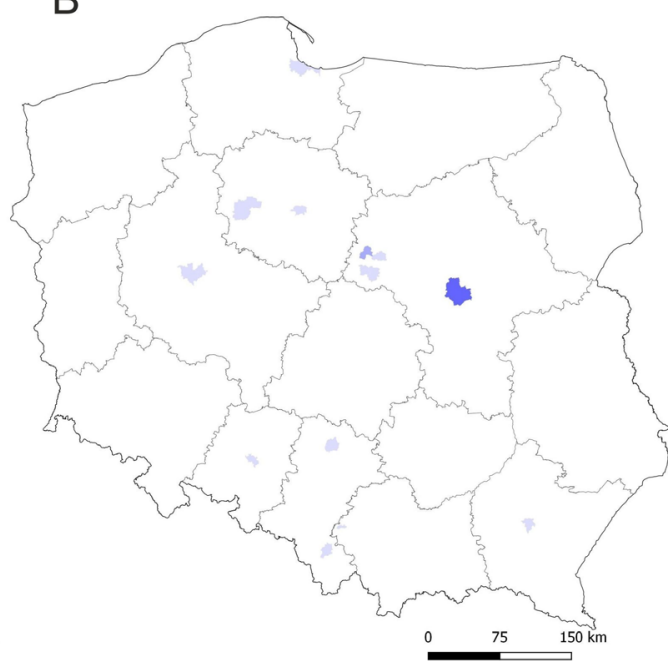

Figure 11. Number of companies that relocated to Płock from other municipalities (inflow)

$A$ - all companies

$B$ - all companies excluding sole proprietorships

Source: own study based on data from the Statistical Office in Warsaw.

Table 3. National context of cities' relations with Warsaw

\begin{tabular}{|c|c|c|c|c|}
\hline \multirow{2}{*}{ City } & \multicolumn{2}{|c|}{ LQ* including Warsaw $^{*}$} & \multicolumn{2}{c|}{ LQ including Warsaw and excluding sp** } \\
\cline { 2 - 5 } & inflow & outflow & inflow & outflow \\
\hline Ciechanów & 3.7 & 4.4 & 4.1 & 1.8 \\
\hline Ostrołęka & 3.8 & 3.2 & 4.1 & 2.4 \\
\hline Płock & 3.5 & 3.7 & 2.6 & 2.7 \\
\hline Radom & 4.1 & 4.5 & 2.7 & 2.5 \\
\hline Siedlce & 3.8 & 4.3 & 1.7 & 1.8 \\
\hline
\end{tabular}

Source: own study based on data from the Statistical Office in Warsaw.

* calculated as the quotient of inflow / outflow from / to Warsaw in relation to the national values.

* * sole proprietorships 
A

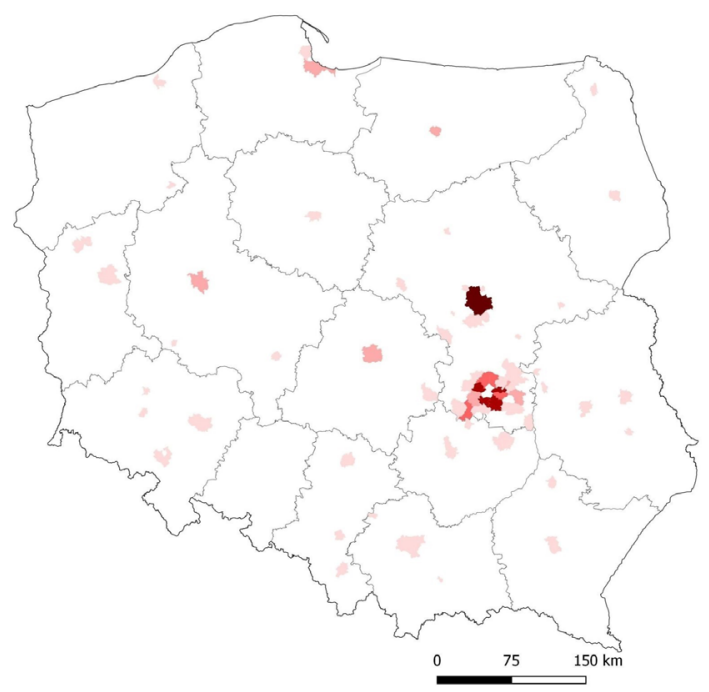

B

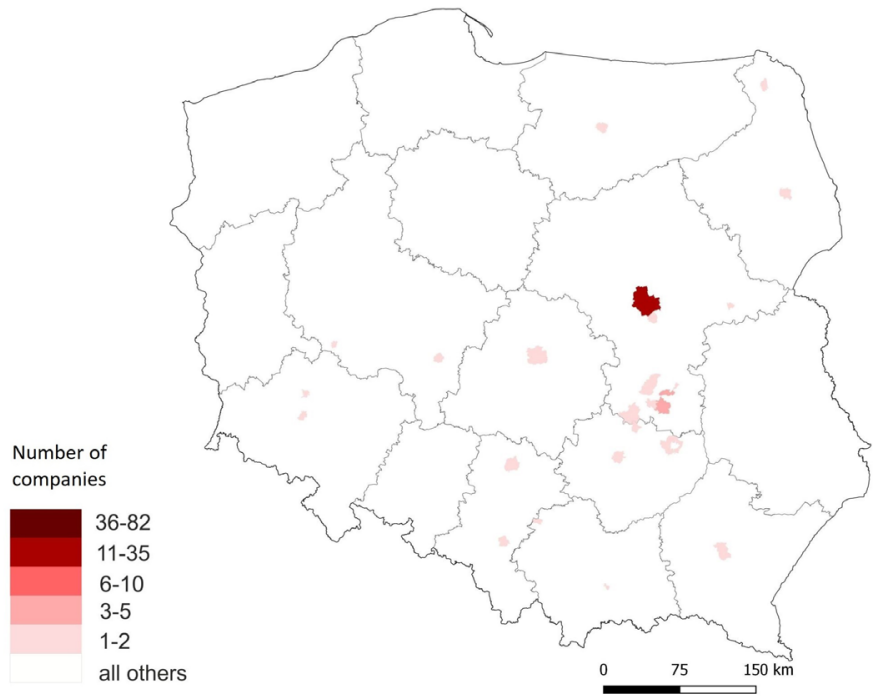

companies

all others

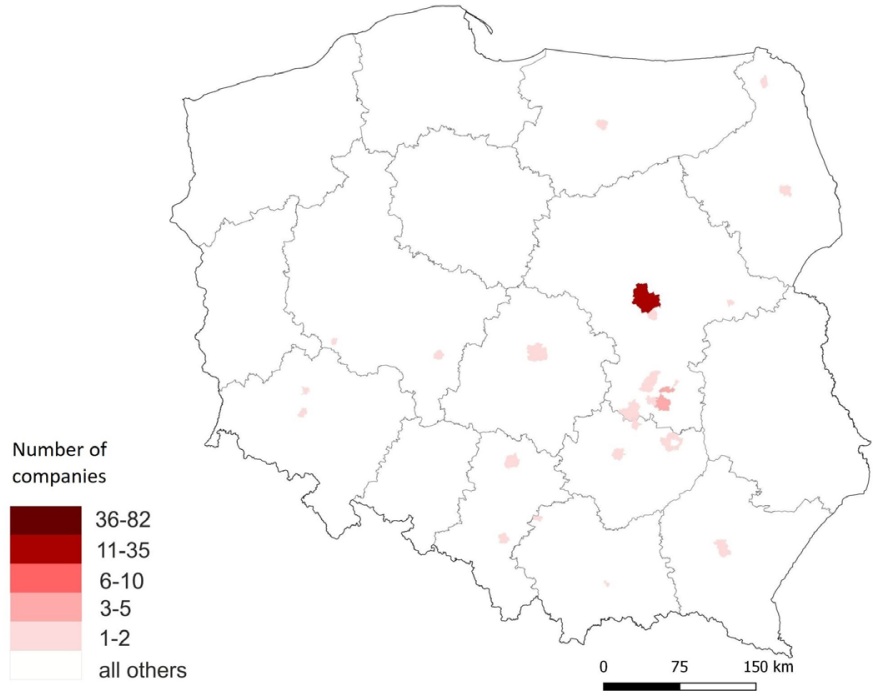

Figure 12. Number of companies that relocated from Radom to other municipalities (outflow)

A - all companies

$B$ - all companies excluding sole proprietorships

Source: own study based on data from the Statistical Office in Warsaw.

A

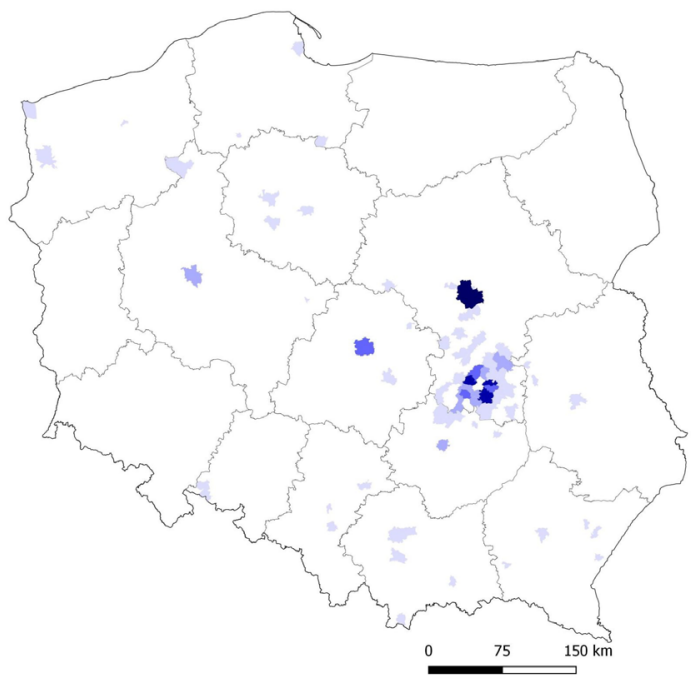

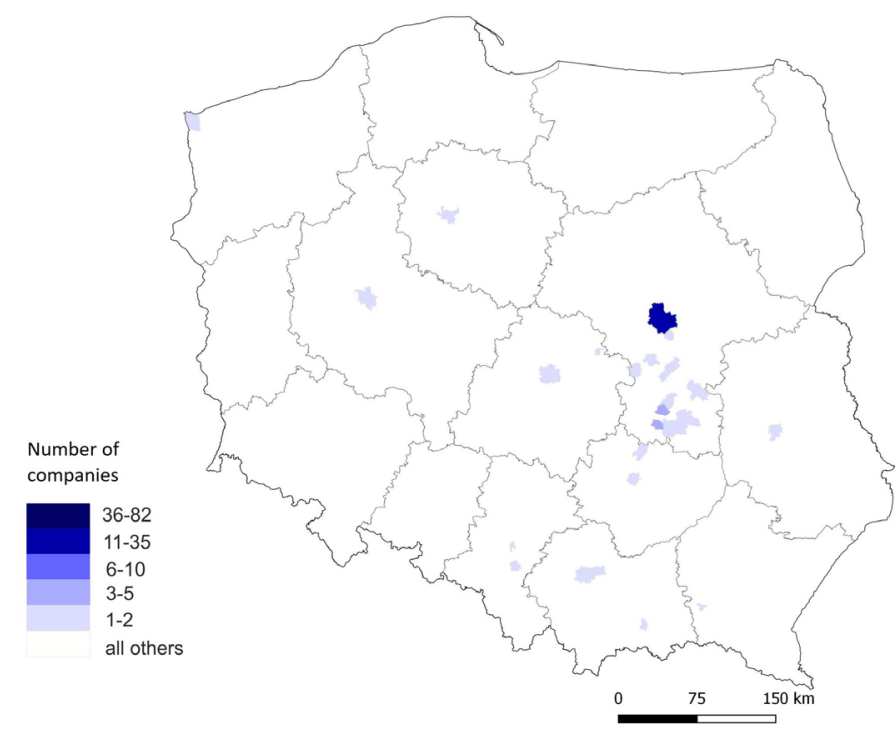

B

Figure 13. Number of companies that relocated to Radom from other municipalities (inflow)

A - all companies

$B$ - all companies excluding sole proprietorships

Source: own study based on data from the Statistical Office in Warsaw.

This paper applies to regional and sub-regional cities that must cope with development difficulties, although it is difficult to put forward a clear thesis on the size of the impact of the loss of the voivodship city status on these cities (Kisiała 2017; Kurniewicz \& Swianiewicz 2016). There is no doubt, however, that a small city will lose out in many ways when in competition with its surroundings or the metropolitan core cities. The loss of capital in the form of microenterprises is obviously associated with economic effects; however, it should be emphasised that those are not as serious as in the case of the relocation of larger companies employing a greater number of employees.

At the same time, the generally large scale of the flow of companies from cities to their closest surroundings allows the statement to be made that, in the case of all cities, although the 
A

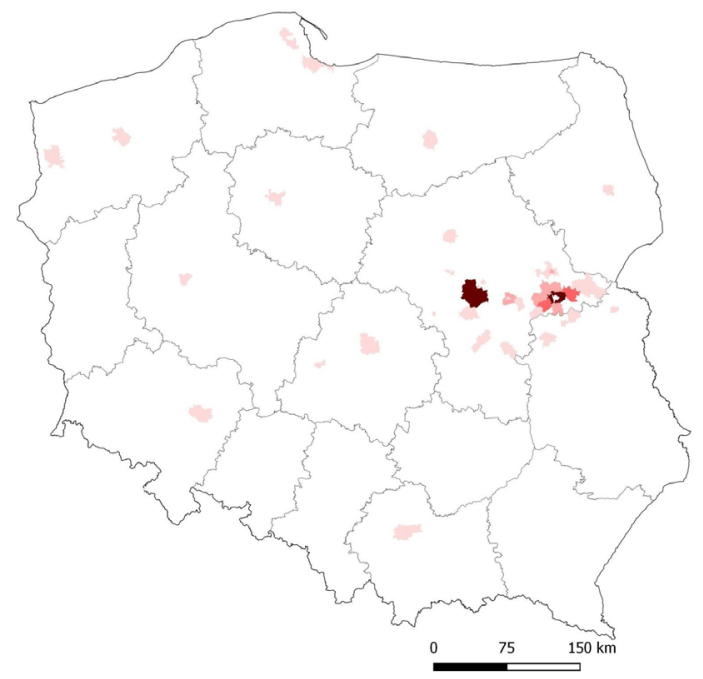

B

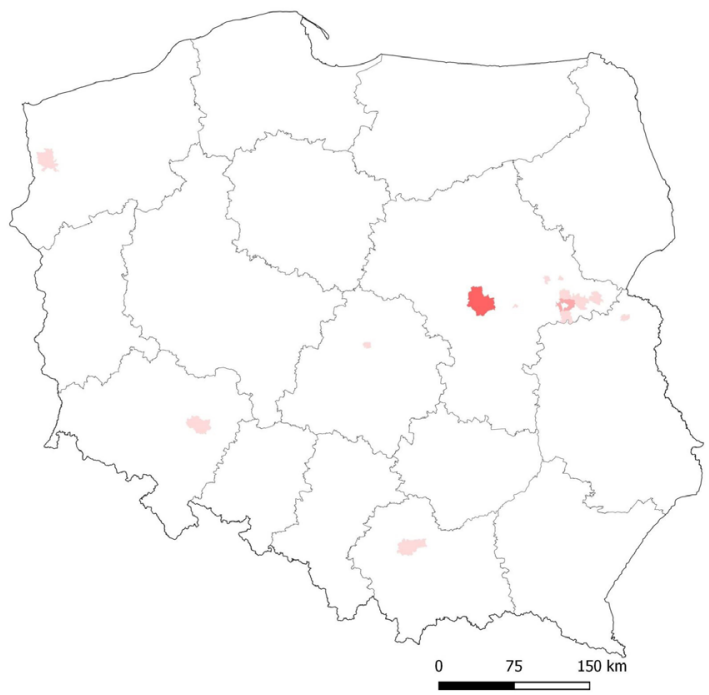

Figure 14. Number of companies that relocated from Siedlce to other municipalities (outflow)

$A-$ all companies

$B$ - all companies excluding sole proprietorships

Source: own study based on data from the Statistical Office in Warsaw.
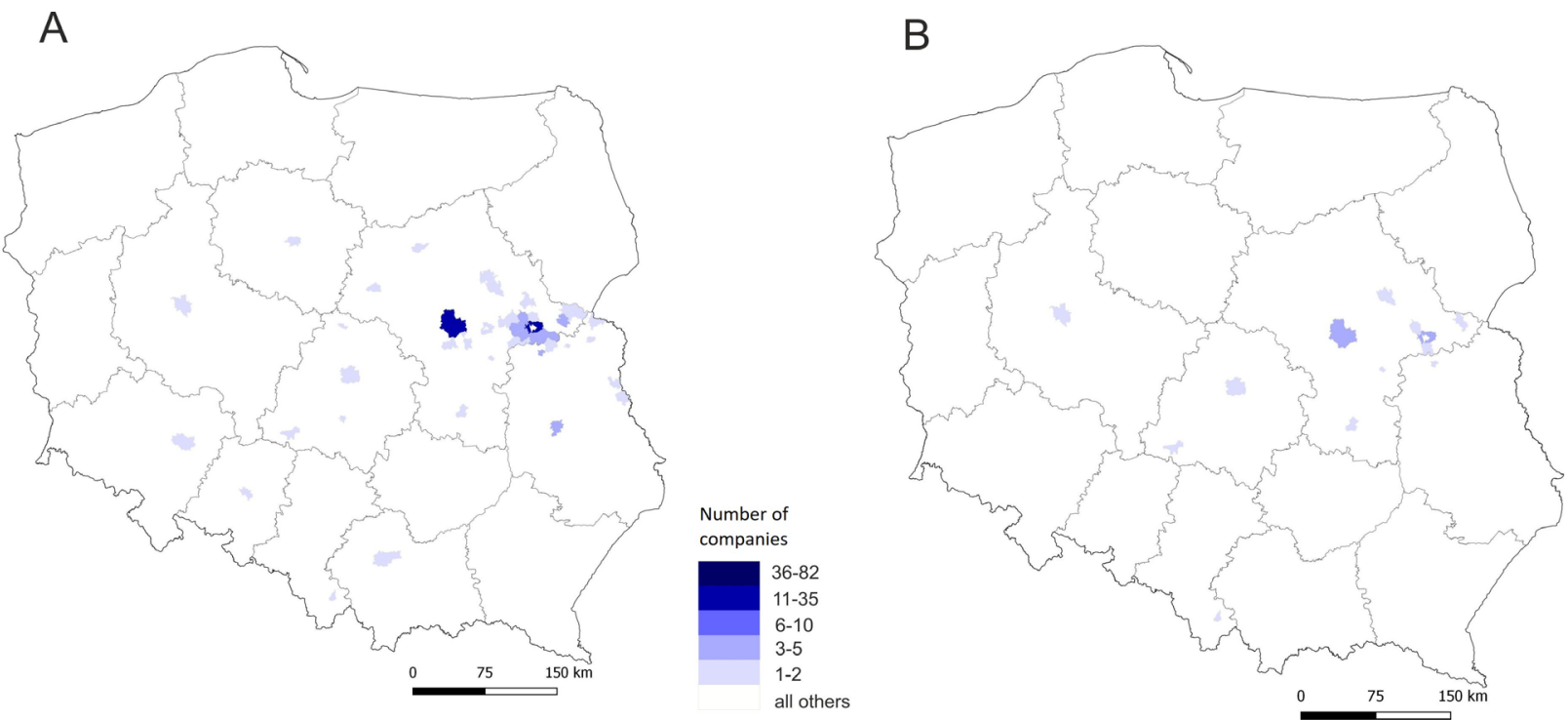

Figure 15. Number of companies that relocated to Siedlce from other municipalities (inflow)

$A$ - all companies

$B$ - all companies excluding sole proprietorships

Source: own study based on data from the Statistical Office in Warsaw.

economic potential (including income tax revenue) of cities (the areas within the borders of the cities only) actually decreases, it allows their functional centres to develop and creates a field for cooperation between the city and the surrounding municipalities.

\section{Summary and conclusions}

The hypothesis that sub-regional centres are drained of resources by Warsaw has been confirmed, especially in the case of Radom, Płock and Siedlce. In these cities the strong negative impact of Warsaw can be seen in the migration of all kinds of companies, including the smallest ones. It means that not only do sole proprietorships migrate to the capital city, a phenomenon which may be connected to population migrations, but larger enterprises do so as well. In Ciechanów, the strong influence of Warsaw was virtually eliminated after excluding sole proprietorships from the analysis. At the same time, it should be emphasised that Warsaw has a much stronger impact on other municipalities. A specific case is Ostrołęka, in which the phenomenon of suburbanisation, which minimises the importance of Warsaw in the migration process, is most strongly marked. 
Each of the cities is characterised by a distinct specificity which may result from the characteristic location, size or socioeconomic structure. The authors of this paper believe that the study constitutes an interesting beginning for further analysis, in terms of company characteristics (the diversification of which affects migration directions) and, probably, business location factors.

\section{Comments}

This article was prepared as part of the cooperation agreement between the Statistical Office in Warsaw and the University of Warsaw. The article is a deepening of the study of the Statistical Office in Warsaw on the subject of migration patterns of enterprises in five cities of the Mazowieckie voivodship (Migrations of enterprises in sub-regional cities... 2018).
This paper is the result of the scientific project 'Dualism in commune development in Poland in the context of policies and aspirations of local communities as well as external factors - compared to the chosen communities in the EU', funded by Narodowe Centrum Nauki (National Science Centre, Poland); grant number DEC-2018/31/B/HS4/00260.

\section{ORCID}

Wojciech Dziemianowicz (1) https://orcid.org/0000-0002-9742-9596 Magdalena Cybulska (1) https://orcid.org/0000-0002-1645-5902

\section{References}

Brouwer, AE, Mariotti, I \& van Ommeren, JN 2004, 'The firm relocation decision: An empirical investigation', The Annals of Regional Science, no 38, pp. 335-347.

Camagni, R 2017, 'On the concept of territorial competitiveness: Soun or misleading?' in Seminal Studies in Regional and Urban Economics, ed. R Capello, Springer International Publishing AG, Cham, pp. 93-113.

Camagni, R, Capello, R \& Caragliu, A 2015, 'Agglomeration economies in large versus small cities: similar laws, high specifities' in The Rise of the City. Spatial Dynamics in the Urban Century, eds. K Kourtit, P Nijkamp \& RR Stough, Edward Elgar Publishing, Cheltenham-Northampton, pp. 85-113.

Capello, R 2009, 'Space, growth and development' in Handbook of Regional Growth and Development Theories, eds. R Capello \& P Nijkamp, Edward Elgar Publishing Limited, Cheltenham - Northampton, pp. 33-52.

Capello, R, Fratesi, U \& Resmini, L 2011, Globalisation and regional growth in Europe: Past trends and future scenarios, Springer-Verlag, Berlin Heidelberg.

Clodnițchi, R 2017, 'Systems competing for mobile factors: Decision making based on hard vs. soft locational factors', Management and Marketing, vol. 12, no 4, pp. 633-651.

Cieślik, A 2005, Geografia inwestycji zagranicznych. Przyczyny i skutki lokalizacji spółek z udziałem kapitału zagranicznego $w$ Polsce [Geography of foreign investments. Causes and effects of location of companies with foreign capital in Poland], Wydawnictwa Uniwersytetu Warszawskiego, Warszawa.

Dej, M 2015, 'Company relocation to rural areas in large metropolitan regions in Poland - Scale and key characteristics' in Young researchers and the problems of polish rural areas, eds. K Zajda \& S Michalska, Wydawnictwo Uniwersytetu Łódzkiego, Łódź, pp. 121-146.

Dej, M, Jarczewski, W \& Chlebicki, M 2018, 'Skala i charakterystyka procesów relokacji przedsiębiorstw w polskich obszarach metropolitalnych - wstępne wyniki badań' ['Scale and characteristics of company relocation processes in major metropolitan areas in Poland - preliminary results'], Studia Regionalne i Lokalne, vol. 72(2), pp.78-98.

Dunning, JH \& Lundan, SM 2008, Multinational Enterprises and the Global Economy, Second Edition, Edward Elgar, Cheltenham and Northampton.

Dziemianowicz, W, Jałowiecki, B \& Krajewska, M 2004, Polityka miejska a inwestycje zagraniczne w polskich metropoliach [Urban policy and foreign investments in Polish metropolises], Wydawnictwo Naukowe SCHOLAR, Warszawa.
Dziemianowicz, W, Mackiewicz, M \& Zaleski, J 2012, 'Konkurencyjność Mazowsza i jej uwarunkowania' ['Competitiveness of Mazovia and its conditions'], Trendy rozwojowe Mazowsza, no. 5/2012, MBPR, Warszawa.

Dziemianowicz, W, Łukomska, J \& Ambroziak, AA 2019, 'Location factors in foreign direct investment at the local level: the case of Poland', Regional Studies, vol. 53, iss. 8, pp. 1182-1192.

Główny Urząd Statystyczny 2020, Bank Danych Lokalnych. Available from: <https://bdl.stat.gov.pl/BDL/start>. [20 April 2020].

Grabow, B, Henckel, D \& Hollbach-Grömig, B 1995, Weiche Standortfaktoren [Soft location factors], W. Kohlhammer $\mathrm{GmbH} /$ Deutscher Gemeindeverlag, Stuttgart.

Grzeszczak, J 1978, Teoria biegunów wzrostu. Przegląd zagranicznej literatury geograficznej [The theory of growth poles. Review of foreign geographic literature], Instytut Geografii i Przestrzennego Zagospodarowania, Zeszyt 3-4, Wrocław, Warszawa, Kraków, Gdańsk.

Grzeszczak, J 1999, 'Bieguny wzrostu a formy przestrzeni spolaryzowanej' ['The poles of growth and forms of polarized space'], Prace geograficzne, vol. 173, IGiPZ PAN, Wydawnictwo Continuo, Wrocław.

Hoover, EM 1962, Lokalizacja działalności gospodarczej [Location of the economic activity], PWN, Warszawa.

Jarczewski, W 2012, Pozyskiwanie inwestorów do gmin [Attracting investors to municipalities], Wolters Kluwer Polska, Warszawa.

Jirásková, E 2013, 'Regions competitiveness increase by improving conditions for industry and services', Journal of Competitiveness, vol. 5, no 1, pp. 68-81.

Kisiała, W 2017, 'Wpływ utraty statusu ośrodka wojewódzkiego na rozwój miast' ['The influence of the loss of the state of a provincial capital on the development of cities'], Prace naukowe Uniwersytetu Ekonomicznego we Wrocławiu, vol. 477, pp. 117-126.

Korcelli-Olejniczak, E \& Korcelli, P 2015, 'On European metropolisation scenarios and the future course of metropolitan development in Poland', Geographia Polonica, vol. 88(1), pp. 107-121.

Kurniewicz, A \& Swianiewicz, P 2016, 'Ból fantomowy czy realna strata? Wpływ utraty statusu stolicy województwa na rozwój gospodarczy i miejsce w hierarchii systemu osadniczego' ['Phantom pain or a real loss? The impact of the loss of regional capital status on economic development and position in the hierarchy of the settlement system'], Prace $i$ Studia Geograficzne, vol. 61, no. 2, pp.25-50. 
Leigh, NG \& Blakely, EJ 2017, Planning local economic development: theory and practice. Thousand Oaks, CA: SAGE Publications.

Maier, G \& Trippl, M 2009, 'Location/allocation of regional growth' in Handbook of Regional Growth and Development Theories, eds. R Capello \& P Nijkamp, Edward Elgar Publishing Limited, Cheltenham - Northampton, pp. 53-65.

Małuszyńska, E 2013, Migracje i delokalizacja przedsiębiorstw [Enterprise migrations and relocation], Wydawnictwo Uniwersytetu Ekonomicznego w Poznaniu, Poznań.

McCann, P \& Sheppard, S 2003, 'The rise, fall and rise again of Industrial Location Theory', Regional Studies, vol. 37, no 6-7, pp. 649-663.

McCann, P \& van Oort, F 2009, 'Theories of agglomeration and regional economic growth: a historical review' in Handbook of Regional Growth and Development Theories, eds. R Capello \& P Nijkamp, Edward Elgar Publishing Limited, Cheltenham - Northampton, pp. 19-32.

Migracje przedsiębiorstw $w$ miastach subregionalnych województwa mazowieckiego w latach 2014-2016 [Migrations of enterprises in sub-regional cities of the Mazowieckie voivodship in the years 2014-2016] 2018, Urząd Statystyczny w Warszawie, Warszawa.

Minerva, GA \& Ottaviano, G 2009, 'Endogenous growth theories: agglomeration benefits and transportation costs' in Handbook of Regional Growth and Development Theories, eds R Capello \& P Nijkamp, Edward Elgar Publishing Limited, Cheltenham - Northampton, pp. 86-97.

Myrdal, G 1957, Economic theory and under-developed regions, Duckworth, London.

Niedomysl, T, Källström, J, Koster, S \& Östh, J 2019, Interregional migration of business owners: who moves and how does moving affect firm performance?, Regional Studies, vol. 53, no 4, pp. 503-516.

Perroux, F 1978, 'Note sur la notion de „pole de croissance”,' Economie Appliquee, vol. VIII, no. 1-2, pp. 307-320.

Perry, M 2010, Controversies in local economic development. Stories, strategies, solutions, Routledge, London-New York.

Rossi, F \& Dej, M 2020, 'Where do firms relocate? Location optimisation within and between Polish metropolitan areas', Annals of Regional Science, vol. 64, pp. 615-640.

Strategia Rozwoju Województwa Mazowieckiego [Development Strategy of the Mazowieckie Voivodeship] 2013, Samorząd Województwa Mazowieckiego, Warszawa.

Szlachta, J 2011, 'Ośrodki subregionalne w Polsce - identyfikacja' ['Subregional centers in Poland - identification'] in Subregional growth poles in Poland, eds. W Dziemianowicz, J Szlachta \& K Szmigiel-Rawska, WGiSR, Uniwersytet Warszawski, Warszawa, pp. 29-39.

Weber, A 1909, Uber den Standort der Industrien [On the location of the industries], Verlag von J. C. B. Mohr (Paul Siebeck), Tubingen.

Wojnicka-Sycz, E 2013, Model terytorialnego bieguna wzrostu jako systemu czynników rozwojowych [The model of territorial growth pole as a system of development factors], Wydawnictwo Uniwersytetu Gdańskiego, Gdańsk.

Zdanowska, N 2017, 'Distribution of foreign direct investment across the national urban systems in countries of Central and Eastern Europe in 2013', Geographia Polonica, vol. 90, Issue 2, pp. 5-24. 
Annex. Company migration zones by category of areas in 2014-2016

\begin{tabular}{|c|c|c|c|c|c|}
\hline & \multirow{2}{*}{$\begin{array}{l}\text { migration zone } \\
\text { all companies }\end{array}$} & \multicolumn{2}{|c|}{ total net migration } & \multicolumn{2}{|c|}{$\begin{array}{c}\text { net migration } \\
\text { - dominating municipality }\end{array}$} \\
\hline & & $\begin{array}{l}\text { excluding sole } \\
\text { proprietorships }\end{array}$ & all companies & $\begin{array}{l}\text { excluding sole } \\
\text { proprietorships }\end{array}$ & \\
\hline \multicolumn{6}{|c|}{ Ciechanów } \\
\hline \multirow{2}{*}{ COUNTY } & suburban zone & -6 & -1 & -5 & -1 \\
\hline & other municipalities & 1 & 1 & -3 & 2 \\
\hline \multirow{2}{*}{$\mathrm{RWS}^{*}$} & Warsaw & -14 & -1 & - & - \\
\hline & other municipalities & -10 & -2 & -3 & -2 \\
\hline \multicolumn{2}{|r|}{ others } & -3 & -2 & $2 /-2$ & $1 /-1$ \\
\hline \multicolumn{6}{|c|}{ Ostrołęka } \\
\hline \multirow{2}{*}{ COUNTY } & suburban zone & -25 & -2 & -17 & -2 \\
\hline & other municipalities & 5 & -1 & -2 & -1 \\
\hline \multirow{2}{*}{ RWS } & Warsaw & -10 & 0 & - & - \\
\hline & other municipalities & -5 & 2 & $1 /-1$ & 1 \\
\hline & others & -4 & $1 /-1$ & -5 & -1 \\
\hline \multicolumn{6}{|c|}{ Płock } \\
\hline \multirow{2}{*}{ COUNTY } & suburban zone & -42 & 3 & -26 & 4 \\
\hline & other municipalities & 3 & -5 & 3 & -2 \\
\hline \multirow{2}{*}{ RWS } & Warsaw & -27 & -15 & - & - \\
\hline & other municipalities & -4 & -1 & $1 /-1$ & -1 \\
\hline & others & -3 & -3 & $3 /-3$ & -3 \\
\hline \multicolumn{6}{|c|}{ Radom } \\
\hline \multirow{2}{*}{ COUNTY } & suburban zone & -37 & -2 & -12 & -2 \\
\hline & other municipalities & -1 & 0 & -3 & $1 /-1$ \\
\hline \multirow{2}{*}{ RWS } & Warsaw & -42 & -9 & - & - \\
\hline & other municipalities & -2 & 0 & -2 & 0 \\
\hline & others & -7 & 5 & -4 & 3 \\
\hline \multicolumn{6}{|c|}{ Siedlce } \\
\hline \multirow{2}{*}{ COUNTY } & suburban zone & -15 & -2 & -15 & -2 \\
\hline & other municipalities & -8 & -1 & -6 & $1 /-1$ \\
\hline \multirow{2}{*}{ RWS } & Warsaw & -24 & -4 & - & - \\
\hline & other municipalities & -6 & -1 & -2 & -1 \\
\hline & others & -6 & 1 & 3 & 2 \\
\hline
\end{tabular}

${ }^{*}$ RWS - Warsaw - capital of region (Region Warszawski Stołeczny)

The net migration for the dominating municipality is the highest net migration of companies from total municipalities for which flows have occurred (therefore, for some areas it was indicated that the values were positive or negative).

Source: own study based on data from the Statistical Office in Warsaw. 